\title{
PENGARUH MOTIVASI, KEPEMIMPINAN, DAN KOMITMEN ORGANISASI TERHADAP KEPUASAN KERJA KARYAWAN PADA PT. SUPERPOLY INDUSTRY JAKARTA
}

\author{
Junaidi dan Carol Daniel Kadang \\ Program Studi Manajemen, Fakultas Ekonomi dan Bisnis, Universitas Tarumanagara Jakarta \\ Email: junaidi1722@yahoo.co.id
}

\begin{abstract}
This study aims to analyze the influence of motivation, leadership, and organizational commitment on employee job satisfaction at PT Superpoly Industry in Jakarta. This research was conducted by probability sampling method with a type of simple random sampling. The researcher distributed questionnaires to 88 employees of PT Superpoly Industry. Data analysis using Smart PLS analysis. The results of the analysis concluded that motivation, leadership, and organizational commitment significantly influence the job satisfaction of PT Superpoly Industry in Jakarta
\end{abstract}

Keywords: motivation, leadership, organizational commitment and job satisfaction.

Abstrak: Penelitian ini bertujuan untuk menganalisis pengaruh motivasi, kepemimpinan, dan komitmen organisasi terhadap kepuasan kerja karyawan pada PT Superpoly Industry di Jakarta. Penelitian ini dilakukan dengan metode probability sampling dengan jenis simple random sampling. Peneliti menyebarkan kuesioner kepada 88 karyawan PT Superpoly Industry. Analisis data menggunakan analisis Smart PLS. Hasil analisis menyimpulkan bahwa motivasi, kepemimpinan, dan komitmen organisasi berpengaruh signifikan terhadap kepuasan kerja PT Superpoly Industry di Jakarta.

Kata kunci: motivasi, kepemimpinan, komitmen organisasi dan kepuasan kerja.

\section{LATAR BELAKANG}

Saat ini kepuasan kerja karyawan merupakan salah satu topik yang senantiasa menarik dan dianggap penting, baik oleh ilmuwan maupun praktisi, justru karena kepuasan kerja dipandang mempengaruhi jalan organisasi secara keseluruhan. Setiap organisasi memiliki tujuan untuk mencapai kinerja yang seoptimal mungkin. Peningkatan kinerja organisasi harus berusaha untuk meningkatkan kepuasaan dari anggota organisasi

Banyak hal yang dilakukan perusahaan untuk memenuhi keinginan karyawan dengan tujuan untuk meningkatkan produktifitasnya dan juga menjaga kepuasan kerja karyawannya. Karyawan yang puas akan bekerja tanpa beban dan memberikan usaha lebih kepada pekerjaannya, serta setia kepada perusahaan dan pimpinannya. Perusahaan dapat kurang memperhatikan kebutuhan dan keinginan karyawannya, sehingga kepuasan kerja menurun. Ini pada akhirnya menimbulkan banyak masalah dalam pekerjaan seperti turunnya disiplin kerja karyawan, turn over karyawan yang tinggi serta menurunkan kinerja perusahaan secara drastis. Hal tersebut sangat merugikan perusahaan, dikarenakan perusahaan harus mengeluarkan bermacam biaya, misalnya pesangon, dan perekrutan karyawan baru yang menghabiskan banyak biaya. Menurut Timotius (2016:244) kepuasan kerja adalah keadaan menyenangkan yang dialami individu dalaam organisasi oleh berbagai hal yang menjadi penyebabnya. 
Banyak faktor yang biasa mempengaruhi kepuasan kerja karyawan, dan saling berkaitan. Faktor yang mempengaruhi kepuasan kerja karyawan di antaranya adalah motivasi, kepemimpinan dan komitmen organisasi (Joharis, 2017). Pada perusahaan pemberian motivasi untuk karyawan merupakan aspek penting dalam meningkatkan kepuasan kerja karyawan. Jika kepuasan kerja karyawan terpenuhi, bukan tidak mungkin maka kinerja yang dihasilkan karyawanpun akan maksimal (Mustaqim, 2016). Menurut Darmadi (2018:125), motivasi merupakan dorongan dasar yang menggerakkan seseorang bertingkah laku. Dalam hal ini motivasi adalah serangkaian dorongan yang dirumuskan secara sengaja oleh perusahaan kepada karyawan agar mereka bersedia secara ikhlas melakukan perilaku tertentu yang berdampak kepada peningkatan kinerja dalam rangka pencapaian perusahaan yang telah di tetapkan sebelumnya. Motivasi merupakan penggerak dan pendorong individu untuk melaksanakan kegiatan guna mencapai suatu tujuan. Motivasi bisa datang dari dalam diri sendiri maupun dorongan orang lain. Dalam organisasi seorang pemimpin harus dapat memotivasi pegawai, seorang pemimpin harus dapat meningkatkan semangat dan gairah kerja, harus dapat meningkatkan prestasi kerja, harus mampu meminimalisir kesalahan yang mungkin terjadi, harus mampu meminimalisir konflik dalam organisasi serta harus mampu menciptakan produktivitas kerja dan meningkatkan kepuasan kerja.

Selain motivasi, yang dapat meningkatkan kepuasan kerja adalah kepemimpinan, kepemimpinan mempunyai peranan sentral dalam kehidupan organisasi maupun kelompok. Untuk mencapai tujuan bersama, manusia di dalam organisasi perlu membina kebersamaan dengan mengikuti pengendalian dari pemimpinnya. Dengan pengendalian tersebut, perbedaan keinginan, kehendak, kemauan, perasaan, dan kebutuhan dipertemukan untuk digerakkan ke arah yang sama. Dengan demikian berarti di dalam setiap organisasi perbedaan individual dimanfaatkan untuk mencapai tujuan yang sama sebagai kegiatan kepemimpinan. Hasibuan (2008, 170) menerangkan bahwa kepemimpinan adalah kepemimpinan adalah cara seorang pemimpin mempengaruhi perilaku bawahan agar mau bekerja sama dan bekerja secara produktif untuk mencapai tujuan organisasi Jadi seorang pemimpin harus mampu memengaruhi para bawahannya untuk bertindak sesuai dengan visi, misi dan tujuan perusahaan. Pemimpin harus bisa memberikan wawasan, membangkitkan kebanggaan, serta menumbuhkan sikap hormat dan kepercayaan dari bawahannya. Pemimpin yang efektif adalah pemimpin yang mengakui kekuatan penting yang terkandung dalam individu. Setiap individu mempunyai kebutuhan dan keinginan yang berbeda. Setiap individu mempunyai tingkat keahlian yang berbeda pula. Pemimpin harus fleksibel dalam memahami segala potensi yang dimiliki oleh individu dan berbagai masalah yang dihadapi oleh individu tersebut. Dengan melakukan pendekatan tersebut pemimpin dapat menerapkan segala peraturan dan kebijakan organisasi serta melimpahkan tugas dan tanggung jawab dengan tepat. Hal ini sejalan dengan usaha untuk menumbuhkan komitmen organisasi dari diri karyawan. Pemimpin nantinya dapat meningkatkan kepuasan karyawan

Aspek yang tak kalah pentingnya adalah sikap-sikap yang berhubungan dengan pekerja itu sendiri (work-releated attitudes) " work - releated attitudes" salah satunya adalah komitmen seorang karyawan terhadap organisasi yang mempekerjakannya. Schermerhorn, et al., (2011: 72) menyatakan komitmen sebagai loyalitas seorang individu pada organisasi. Pentingnya peran komitmen organisasi, sehingga beberapa organisasi berani memasukkan unsur komitmen sebagai salah satu syarat untuk memegang suatu jabatan atau posisi yang ditawarkan dalam iklan-iklan lowongan pekerjaan. Meskipun komitmen organisasi memegang peranan penting, namun tidak jarang pengusaha maupun pegawai masih belum memahami arti komitmen secara sungguh-sungguh. Padahal pemahaman tersebut sangatlah penting agar tercipta kondisi kerja yang kondusif, sehingga perusahaan dapat berjalan secara efisien dan efektif. Terciptanya kondisi kerja yang kondusif dan mampu menghasilkan 
kinerja yang efisien dan efektif dapat meningkatkan kepuasan kerja pegawai. Menurut Soekidjan (2009:36) menjelaskan bahwa secara umum komitmen kuat terhadap organisasi terbukti, meningkatkan kepuasan kerja, mengurangi absensi dan meningkatkan kinerja.

\section{KAJIAN TEORI}

Menurut Robbins and Judge (2008:222), "Motivasi adalah proses yang menjelaskan mengenai kekuatan, arah, dan ketekunan seseorang dalam upaya untuk mencapai tujuan" Menurut Fahmi (2013:45), "motivasi kerja adalah aktivitas perilaku yang bekerja dalam usaha untuk memenuhi kebutuhan- kebutuhan yang diinginkan." Sedangkan menurut Darmadi (2018: 125): "Motivasi adalah kekuatan, baik dari dalam maupun dari luar yang mendorong seseorang untuk mencpai tujuan tertentu yang telah ditetapkan sebelumnya".

Menurut Hasibuan (2008, 170) kepemimpinan adalah "cara seorang pemimpin mempengaruhi perilaku bawahan agar mau bekerja sama dan bekerja secara produktif untuk mencapai tujuan organisasi". Soekarso dan Iskandar (2015:58) menyatakan "Kepemimpinan merupakan proses pengaruh sosial dalam hubungan interpersonal, penetapan keputusan, dan pencapaian tujuan".

Robbins dan Judge (2008:125) mendefenisikan :komitmen organisasi adalah sebagai suatu keadaan dimana seorang individu memihak organisasi serta tujuan-tujuan dan keinginan untuk mempertahankan keanggotaannya dalam organisasi." Menurut Utaminingsih (2014:144): "Komtimen organisasi adalah keinginan para anggota organisasiuntuk tetap mempertahankan keanggotaannya dalam organisasi dan bersedia melakukan usaha yang tinggi bagi pencapaian tujuan organisasi”.

\section{Kaitan Antar Variabel}

\section{Pengaruh Motivasi terhadap Kepuasan Kerja}

Motivasi merupakan hal yang sangat diperlukan oleh setiap karyawan di dalam suatu perusahaan, sebab motivasi merupakan suatu dorongan yang ada dalam diri seseorang dalam usahanya memenuhi keinginan, maksud, dan tujuan. Pemberian motivasi dalam bekerja kepada karyawan adalah faktor yang penting dalam organisasi. Motivasi atau dorongan kepada karyawan akan meningkatkan semangat dalam melakukan pekerjaan sehingga dapat memperoleh output yang sesuai target perusahaan. Dengan didapatnya target yang tentukan, maka akan timbul rasa puas dalam diri karyawan

Penelitian Sundarminingsih, dkk (2016) menyimpulkan bahwa motivasi berpengaruh terhadap kepuasan kerja karyawan. Dengan adanya motivasi dalam diri pegawai tentunya akan membuat mereka bekerja dengan serius, tekun, bergairah dan memiliki semangat kerja yang tinggi yang nantinya akan berpengaruh terhadap hasil kerja. Hasil kerja yang melampuai target akan mempengaruhi tingkat kepuasan kerja. Kemudian Anggita, dkk. (2017) juga melakukan penelitian mengenai pengaruh motivasi dan komitmen organisasi terhadap kepuasan kerja. Hasil penelitiannya menunjukkan bahwa motivasi berpengaruh terhadap kepuasan kerja karyawan.

\section{Pengaruh Kepemimpinan Terhadap Kepuasan Kerja}

Kepemimpinan dalam suatu organisasi merupakan suatu faktor yang menentukan atas berhasil tidaknya suatu organisasi. Kepemimpinan yang sukses menunjukkan bahwa pengelolaan suatu organisasi berhasil dilaksanakan dengan sukses pula. Kepemimpinan adalah perilaku atau cara yang dipilih dan dipergunakan pemimpin dalam mempengaruhi pikiran, perasaan, sikap dan perilaku para anggota organisasi/bawahan. Kepemimpinan erat 
hubungannya dengan kepuasan kerja karyawan karena tindakan pemimpin dapat menghilangkan kekecewaan karyawan terhadap pekerjaannya.

Penelitian Joharis (2017) menyimpulkan bahwa kepemimpinan berpengaruh terhadap kepuasan kerja karyawan. Pemimpin merupakan pencetus tujuan, merencanakan, mengerakan dan mengorganisasikan seluruh sumber daya yang dimiliki oleh perusahaan dalam rangka mencapai tujuan yang diinginkan. Karyawan tidak akan menunjukkan pelayanan dan kinerja yang baik jika mereka merasa tidak bahagia dengan pekerjaanya, bosnya dan perusahaan tempat dia bekerja. Rasa puas atau tidak puas dari karyawan berada dalam control pemimpin perusahaan. Kepuasan kerja dapat berjalan dengan baik apabila kepemimpinan dapat menyesuaikan dengan situasi dan kondisi, sehingga dapat ditentukan langkah langkah perbaikan untuk lebih memacu tingkat kepuasan. Kemudian Sundarminingsih, dkk (2016) juga melakukan penelitian mengenai pengaruh kepemimpinan, motivasi kerja dan lingkungan terhadap kepuasan kerja, hasil penelitian menunjukkan bahwa kepemimpinan berpengaruh terhadap kepuasan kerja karyawan.

\section{Pengaruh Komitmen Organisasi terhadap Kepuasan Kerja}

Komitmen organisasional merupakan suatu keadaan yang menunjukkan adanya keterikatan psikologis seorang pegawai pada suatu organisasi untuk loyal dan terlibat dalam organisasi. Semakin loyal seorang pegawai maka semakin tinggi pula komitmen organisasionalnya. Sundarminingsih, dkk (2016) dalam penelitiannya menyatakan bahwa komitmen organisasi berpengaruh signifikan terhadap kepuasan kerja karyawan. Semakin tinggi komitmen karyawan terhadap organisasi menunjukkan adanya kepuasan karyawan dalam bekerja

Penelitian Dessyarti (2018) mengungkapkan bahwa komitmen organisasi mempengaruhi kepuasan kerja karyawan. Arifah dan Romadhon (2015) juga menyatakan bahwa komitmen organisasi berpengaruh positif terhadap kepuasan kerja karyawan. Komitmen akan mencerminkan tingkat kesungguhan pegawai dalam menjalankan tugas dan fungsinya. Sebab adanya komitmen yang tinggi akan memberikan pengaruh positif terhadap kepuasan kerja pegawai.

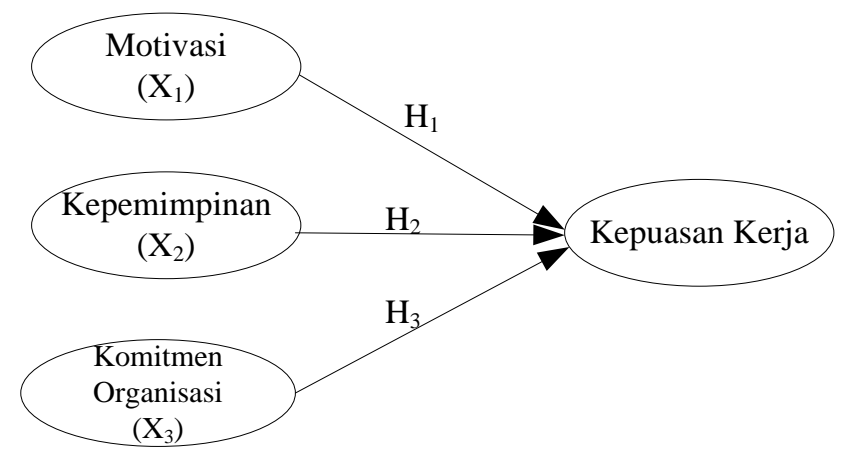

Gambar 1. Kerangka Pemikiran berikut:

Berdasarkan kerangka pemikiran diatas maka hipotesis penelitian ini adalah sebagai

$\mathrm{H}_{1}$ : Terdapat pengaruh signifikan motivasi terhadap kepuasan kerja karyawan

$\mathrm{H}_{2}$ : Terdapat pengaruh signifikan kepemimpinan terhadap kepuasan kerja karyawan

$\mathrm{H}_{3}$ : Terdapat pengaruh signifikan komitmen terhadap kepuasan kerja karyawan 


\section{METODE PENELITIAN}

Penelitian ini menggunakan disain penelitian deskriptif yang bertujuan membuat deskriptif secara sistematis, faktual, dan akurat mengenai fakta-fakta dan sifat-sifat dari populasi. Melalui penerapan metode deskriptif diharapkan peneliti mendapatkan informasi yang tepat dan akurat serta gambaran korelasi dari pengaruh motivasi (X1), kepemimpinan (X2), dan komitmen organisasi (X3) terhadap kepuasan kerja karyawan (Y). Populasi dalam penelitian ini adalah seluruh karyawan PT. Superpoly Industry sebanyak 113 karyawan. Jumlah sampel sebanyak 88 responden

Data dianalisis menggunakan PLS-SEM dimana data diolah dengan program software SmartPLS 3. Pertama, pengolahan dilakukan pada outer model untuk menguji validitas (konvergen dan diskriminan) dan reliabilitas. Uji validitas konvergen dilihat dari nilai outer loadings di antara 0,5-0,7 kemudian AVE > 0,5. Selanjutnya untuk uji validitas diskriminan, beracuan pada Fornell-Larcker Criterion dan Cross Loadings. Kemudian pada analisis reliabilitas, beracuan pada nilai cronbach's alpha dan composite reliability $>0,7$.

Kedua, pengolahan dilakukan pada inner model untuk menguji hipotesis yang telah dihasilkan. Sebelum pengujian hipotesis, pertama dilakukan pengujian hubungan antar konstruk dengan melihat nilai $\mathrm{R}$-square $\left(\mathrm{R}^{2}\right)$ dengan kriteria $(1-0,75)$ "bersifat kuat", $(0,74$ $-0,5)$ "bersifat moderat", dan $(0,49-0,25)$ "bersifat lemah", dan nilai GoF (Goodness of Fit) dengan kriteria 0,1 "kelayakan model kecil", 0,25 "kelayakan model sedang", dan 0,36 "kelayakan model besar" (Tenenhaus, 2005). Selanjutnya pengujian hipotesis, untuk melihat pengaruh yang terjadi lihat (positif/ negatif) dari coefficient yang dihasilkan, dan menggunakan $t$-statistics $>1,645$ (hipotesis tidak ditolak) dan $p$-values $<0,05$ (hipotesis signifikan)

\section{Hasil Uji Statistik \\ Hasil Uji validitas}

Pada hasil validitas konvergen, didapatkan semua angka $>0,5$ pada nilai outer loadings untuk setiap pernyataannya, dan didapatkan semua angka $>0,5$ pada nilai Average Variance Extracted / AVE maka pernyataan yang digunakan sudah valid secara validitas konvergen. Selain itu, pada hasil validitas diskriminan, peneliti menggunakan nilai Cross Loadings dimana nilai korelasi antara pernyataan terhadap variabel nya sendiri harus lebih besar daripada pernyataan terhadap variabel lainnya berdasarkan hasil kalkulasi SmartPLS 3, didapatkan semua angka pada pernyataan terhadap variabel-nya sendiri lebih besar daripada terhadap variabel lainnya maka pernyataan sudah valid secara validitas diskriminan.

\section{Hasil Uji reliabilitas}

Pada hasil reliabilitas, maka berdasarkan hasil yang dikalkulasi oleh program SmartPLS 3, didapatkan semua angka pada nilai Cronbach's Alpha untuk setiap pernyataannya adalah $>0,7$ dan pada nilai Composite Reliability didapatkan semua angka untuk setiap pernyataannya adalah $>0,7$. Maka pernyataan yang digunakan dalam penelitian ini sudah reliabel berdasarkan kedua nilai reliabilitas, yakni Cronbach's Alpha dan Composite Reliability.

\section{Hasil Uji R-Square $\left(\mathbf{R}^{2}\right)$ dan GoF (Goodness of Fit)}

Dapat diketahui nilai $R$ Square adalah sebesar 0,733 , artinya sebesar $73.3 \%$ variasi kepuasan kerja karyawan dapat dijelaskan oleh variasi motivasi, kepemimpinan dan komitmen organisasi. Sisanya sebesar $26,7 \%$ dijelaskan oleh variabel lain. 
Hasil uji GoF, didapatkan nilai GoF sebesar 0,719 yang berarti bahwa keseluruhan dalam kinerja model prediksi yang ditinjau pada tingkat kesesuaian antara inner model dengan outer model adalah besar karena di atas 0,36 .

\section{Hasil Uji Hipotesis}

Tabel 1. Hasil Uji Hipotesis (Bootstrapping)

\begin{tabular}{|l|r|r|r|r|r|}
\hline & $\begin{array}{l}\text { Original } \\
\text { Sample (O) }\end{array}$ & $\begin{array}{l}\text { Sample } \\
\text { Mean (M) }\end{array}$ & $\begin{array}{l}\text { Standar } \\
\text { Deviation } \\
\text { (STDEV) }\end{array}$ & $\begin{array}{l}\text { T Statistics } \\
\text { (JO/STDEV) }\end{array}$ & $\begin{array}{l}\text { P } \\
\text { Value }\end{array}$ \\
\hline Motivasi $\rightarrow$ Kepuasan Kerja & 0.524 & 0.525 & 0.080 & 6.576 & 0.000 \\
\hline $\begin{array}{l}\text { Kepemimpinan } \rightarrow \text { Kepuasan } \\
\text { Kerja }\end{array}$ & 0.237 & 0.222 & 0.102 & 2.325 & 0.020 \\
\hline $\begin{array}{l}\text { Komitmen Organisasi } \rightarrow \\
\text { Kepuasan Kerja }\end{array}$ & 0.218 & 0.234 & 0.095 & 2.308 & 0.021 \\
\hline
\end{tabular}

Sumber: Hasil Olah Data pada SmartPLS3

\section{DISKUSI}

Hipotesis pertama menunjukkan bahwa motivasi terbukti berpengaruh secara signifikan terhadap kepuasan kerja karyawan dengan tingkat keyakinan 95\%. Hal tersebut dari nilai t-statistik sebesar 6,576 yang berarti lebih besar dari 1,96 dan p-values sebesar 0,000 yang berarti lebih kecil dari 0,05. Sehingga dapat disimpulkan bahwa motivasi berpengaruh signifikan terhadap kepuasan kerja karyawan. Hasil penelitian ini sejalan dengan penelitian, Sundarminingsih, dkk (2016), Anggita, dkk. (2017), dan Lianna, dkk (2017) yang menyimpulkan bahwa motivasi berpengaruh terhadap kepuasan kerja. Motivasi atau dorongan kepada karyawan akan meningkatkan semangat dalam melakukan pekerjaan sehingga dapat memperoleh output yang sesuai target perusahaan. Dengan didapatnya target yang tentukan, maka akan timbul rasa puas dalam diri karyawan.

Kemudian untuk Hipotesis yang kedua menunjukkan bahwa variabel kepemimpinan terbukti berpengaruh secara signifikan terhadap kepuasan kerja karyawan karena hasil dari nilai t-statistik kepemimpinan sebesar 2,3256 yang berarti lebih besar dari 1,96 dan p-values sebesar 0,021 yang berarti lebih kecil dari 0,05. Sehingga dapat disimpulkan bahwa kepemimpinan memiliki pengaruh yang signifikan terhadap kepuasan kerja karyawan. Hal tersebut sesuai dengan penelitian yang telah dilakukan, Sundarminingsih, dkk (2016), Dessyarti (2018) dan Joharis (2017) yang menyimpulkan bahwa kepemimpinan berpengaruh positif terhadap kepuasan kerja karyawan. Pemimpin merupakan pencetus tujuan, merencanakan, menggerakan dan mengorganisasikan seluruh sumber daya yang dimiliki oleh perusahaan dalam rangka mencapai tujuan yang diinginkan. Karyawan tidak akan menunjukkan pelayanan dan kinerja yang baik jika mereka merasa tidak bahagia dengan pekerjaanya. Rasa puas atau tidak puas dari karyawan berada dalam control pemimpin perusahaan. Dengan kemampuan yang dimiliki oleh seorang pemimpin, tentunya akan mudah menggerakkan bawahan untuk bekerja dalam rangka pencapaian tujuan organisasi, dengan keberhasilan pencapaian tujuan ini tentunya akan menciptakan kepuasan kerja.

Untuk hipotesis ketiga, dapat disimpulkan komitmen organisasi memiliki pengaruh yang signifikan terhadap kepuasan kerja karyawan dengan tingkat keyakinan 95\%. Hasil penelitian ini sejalan dengan penelitian Sundarminingsih, dkk (2016), Dessyarti (2018), Arifah dan Romadhon (2015) yang menyimpulkan bahwa komitmen organisasi berpengaruh 
terhadap kepuasan kerja. Komitmen organisasi merupakan suatu keadaan yang menunjukkan adanya keterikatan psikologis seorang pegawai pada suatu organisasi untuk loyal dan terlibat dalam organisasi. Semakin loyal seorang pegawai maka semakin tinggi pula komitmen organisasinya. Semakin tinggi komitmen karyawan terhadap organisasi menunjukkan adanya kepuasan karyawan dalam bekerja. Komitmen akan mencerminkan tingkat kesungguhan pegawai dalam menjalankan tugas dan fungsinya. Sebab dengan adanya komitmen yang tinggi akan memberikan pengaruh positif terhadap kepuasan kerja pegawai.

\section{PENUTUP}

Berdasarkan penelitian dan pembahasan, maka dapat diambil beberapa kesimpulan sebagai berikut:

1. Motivasi berpengaruh signifikan terhadap kepuasan kerja pada PT. Superpoly Industry di Jakarta. Semakin baik Motivasi yang diberikan oleh perusahaan maka akan semakin meningkatkan kepuasan kerja pada diri setiap karyawan.

2. Kepemimpinan berpengaruh signifikan terhadap kepuasan kerja pada PT. Superpoly Industry di Jakarta. Semakin baik kepemimpinan suatu organisasi maka semakin tinggi tingkat kepuasan kerja karyawan

3. Komitmen organisasi berpengaruh signifikan terhadap kepuasan kerja pada PT. Superpoly Industry di Jakarta. Apabila komitmen organisasi semakin tinggi maka kepuasan kerja karyawan semakin tinggi, dan apabila komitmen organisasi semakin rendah maka semakin rendah pula kepuasan kerja karyawan.

saran yang dapat diberikan bagi perusahaan dan bagi peneliti lain yaitu:

1. Perusahaan dapat meningkatkan kepuasan kerja dengan cara mengusahakan motivasi kerja yang baik. Perusahaan sebaiknya lebih memperhatikan hubungan antar karyawan dengan unit terkait agar lebih baik, karena hal tersebut merupakan indikator yang paling rendah pengaruhnya terhadap kepuasan kerja karyawan. Selain itu perusahaan juga dapat motivasi dengan memberikan insentif dan penghargaan. Insentif dan penghargaan yang diberikan dapat meningkatkan motivasi karyawan dan meningkatkan kepuasan kerja karyawan.

2. Bagi perusahaan. Dalam hal ini, penulis menyarankan bahwa pimpinan PT. Superpoly Industry di Jakarta sebaiknya dapat memperhatikan dan menunjang peningkatan kepuasan kerja karyawannya agar dapat meningkat dan menjadi lebih baik dengan cara pemimpin perusahaan lebih memperhatikan kepentingan karyawan, pemimpin mendorong dan membantu kelompok dalam menetapkan dan menjelaskan tujuan dan memperhatikan masukan dari karyawan dalam membuat keputusan.

3. Peningkatan kepuasan kerja juga dapat dilakukan dengan cara meningkatkan komitmen organisasional. Perusahaan dapat meningkatkan komitmen karyawan dengan memmenuhi kebutuhan karyawan dengan terpenuhinya kebutuhan karyawan, maka karyawan akan merasa diperhatikan dan akan menimbulkan rasa memiliki terhadap perusahaan sehingga akan meningkatkan komitmen karyawan terhadap perusahaan. Apabila komitmen organisasi semakin tinggi maka kepuasan kerja karyawan semakin tinggi, dan apabila komitmen organisasi semakin rendah maka semakin rendah pula kepuasan kerja karyawan. 


\section{DAFTAR PUSTAKA}

Anggita Mus, Teman Koesmono, Fenika Wulani (2017). Pengaruh Motivasi Kerja dan Komitmen Organisasional terhadap Kepuasan Kerja pada Perawat Rumah Sakit Umum Daerah Bobong. Kajian Ilmiah Mahasiswa Manajemen (KAMMA). Vol 6 No 1: $1-10$

Arifah, Dista Amalia dan Romadhon, Candra (2015) Pengaruh Komitmen Organisasi, Komitmen Profesional Dan Gaya Kepemimpinan Terhadap Kepuasan Kerja Dengan Motivasi Sebagai Variabel Intervening (Studi Empiris pada Kantor Akuntan Publik di Semarang). Converence in business, accounting, and management. Vol. 2 No. 1:357369

Darmadi (2018) Manajemen Sumber Daya Manusia. Yogyakarta: Budi Utama

Dessyarti, Robby Sandhi (2018) Pengaruh Gaya Kepemimpinan, Komitmen Organisasi, Budaya Organisasi terhadap Kepuasan Kerja dan Kinerja Karyawan Pemasaran (pada Dealer Motor PT Suzuki Cabang Madiun dan Ngawi). Jurnal Ilmu Ekonomi, Manajemen, dan Akuntansi. Vol. 7, No 2 :112-124

Fahmi, Irham. (2014). Perilaku Organisasi: Teori, Aplikasi, dan Kasus. Cetakan Kedua. Bandung: Alfabeta.

Hasibuan, M. (2008). Organisasi dan Motivasi. Jakarta: Bumi Aksara

Joharis, M (2017) The Effect Of Leadership, Organizational Culture, Work Motivation And Organizational Commitment On Job Satisfaction Teacher At Senior High School In Medan. The Turkish Online Journal of Design. Vol 2, No. 1: 1415-1425

Mustaqim (2016) The Influence of Leadership Styles and Motivation of Employees Job Satisfaction. International Journal of Economics and Finance. Vol. 8, No. 10: 176183.

Robbins, Stephen P dan Judge, Timothy A. (2008). Perilaku Organisasi. Edisi 12. Jakarta: Selemba Empat.

Schermerhorn, J. R., Hunt, J. G., Osborn, R. N., dan Uhl-Bien, M. (2011). Organizational Behavior 11th Edition. New Jersey: John Wiley \& Sons, Inc

Soekidjan. (2009). Manjaemen Sumber Daya Manusia. Jakarta: Bumi Aksara

Sundarminingsih, Maria Magdalena M., Heru Sri Wulan (2016) Influence Of Motivation, Work Environment And Leadership On The Job Satisfaction And Implications For Performance Of Employees (A Case Study In The Diponegoro Mlitary Command). Journal Of Management. Vol 2 No.2: 1-14

Timotius Duha (2016) Perilaku Organisasi. Yogyakarta: Budi Utama

Utaminingsih, Alifiulahtin (2014) Perilaku Organisasi: Kajian Teoritik dan Empirik Terhadap Budaya Organisasi, Gaya Kepemimpinan, kepercayaan dan komitmen. Malang: UB Press. 